Brazilian Journal

of Chemical

ISSN 0104-6632

Printed in Brazil

Engineering

www.scielo.br/bjce

Vol. 35, No. 02, pp. 553 - 562, April - June, 2018

dx.doi.org/10.1590/0104-6632.20180352s20170036

(cc) BY

\title{
SIMULATED DAIRY WASTEWATER TREATMENT IN A PILOT PLANT SCALE MAGNETO-ACTIVE HYBRID ANAEROBIC BIOFILM REACTOR (MA-HABR)
}

\author{
Marcin Dębowski ${ }^{1}$, Marcin Zieliński ${ }^{1}$, Marta Kisielewska ${ }^{1 *}$, Mirosław \\ Krzemieniewski ${ }^{1}$, Monika Makowska ${ }^{2}$, Marian Grądkowski ${ }^{2}$ and \\ Aneta Tor-Świątek ${ }^{3}$

\begin{abstract}
${ }^{1}$ University of Warmia and Mazury in Olsztyn, Department of Environmental Engineering, Warszawska 117 St., 10-950 Olsztyn, Poland Industrial Biotechnology, Pułaskiego 6/10 St., 26-600 Radom, Poland
\end{abstract} \\ ${ }^{2}$ Institute for Sustainable Technologies, National Research Institute in Radom, Department of \\ ${ }^{3}$ Lublin University of Technology, Department of Polymer Processing, Nadbystrzycka 36 St., \\ 20-618 Lublin
}

(Submitted: January 18, 2017; Revised: May 12, 2017; Accepted: May 14, 2017)

\begin{abstract}
The aim of this study was to determine the effects of magneto-active microporous packing media manufactured by extrusion technology and modified by the addition of relevant amounts of metal catalysts and magnetic activation on the effectiveness of simulated dairy wastewater (SDW) treatment and biogas productivity in a pilot plant scale hybrid anaerobic biofilm reactor with full mixing. The best performance was found at an organic loading rate (OLR) in the range $6.0-8.0 \mathrm{~kg} \mathrm{COD} / \mathrm{m}^{3} \cdot \mathrm{d}$, where the chemical oxygen demand (COD) removal was about $80 \%$, the biogas yield ranged from $256.7-310.9 \mathrm{~L} / \mathrm{kg} \mathrm{COD}$ removed $_{\text {, }}$, the methane production ranged from 420.6 - $557.1 \mathrm{~L} / \mathrm{d}$ and total phosphorus removal ranged from $82.9-90.7 \%$. The study demonstrated that the application of the innovative packing media in the biofilm-bed reactor enhanced the sorption of organic matter, biogas productivity and the binding of biogenic compounds.
\end{abstract}

Keywords: anaerobic digestion, biogas, dairy industry, magneto-active support material, phosphorus removal.

\section{INTRODUCTION}

The dairy industry is one of the main agricultural productions in the world (Chokshi et al., 2016). In 2015, the production of milk in the European Union was approximately 168.2 million tonnes, of which 155.1 million tonnes were delivered to dairies (Eurostat, Statistics Explained). In Poland, the collection of milk by dairies in 2015 was 10.9 million tones (Eurostat,
Statistics Explained).The indicator of waste water volume produced in dairies is about 0.2-10 liters per liter of processed milk with an average generation of about 2.5 liters of wastewater per liter of the milk processed (Sheteand Shinkar, 2013). The daily discharge of dairy wastewater in Poland is approximately 92,000 m3 (Gugała et al., 2015). Dairy processing effluents are generated in an intermittent way with variable flow rates, but generally are characterized by high strength

*Corresponding author: jedrzejewska@uwm.edu.pl 
with a COD concentration up to $95 \mathrm{~g} / \mathrm{L}$ (Chokshi et al., 2016). Although the method of activated sludge wastewater treatment is an efficient solution and usually allows one to achieve the appropriate effluent quality discharged into the receivers surface waters. However, the extensive energy requirements and many technological problems due to the high organic load and variable quality of wastewater indicate the need to use different methods to reduce the treatment costs and intensify the wastewater treatment efficiency. Anaerobic digestion (AD) has been successfully applied in fullscale for the treatment of dairy wastewater (Tiwary et al., 2015). Several bioreactor types have been used; however, granule and biofilm-based reactors are the most common reactor configurations employed (Karadag et al., 2015; Rajagopal et al., 2013).

Anaerobic biofilm reactors are characterized by high loading capacity, resistance to hydraulic and organic overloads, high content of biomass, no requirement of mechanical mixing and short start-up (Ince et al., 2000; Haridas et al., 2005; Karadaget al., 2015). In anaerobic biofilms reactors treating dairy wastewater, microorganisms are supported on filtering materials such as seashells, charcoal, plastic elements, sintered glass, ceramic elements, natural stone and gravel (Ince et al., 2000; Najafpour et al., 2010; Qazi et al., 2011). However, the organic matter removal efficiency is related with the nature and properties of these materials (Karadag et al., 2015). An alternative to the currently used support materials is the use of packing media that enhance the sorption, precipitation and the binding of biogenic compounds. It has been shown that the effective removal of organic matter and phosphorus from dairy wastewater can be achieved by the introduction of metal ions formed during the corrosion of metal elements (Jędrzejewska-Cicińska and Krzemieniewski, 2010). Similarly, a constant magnetic field may significantly improve the efficiency of dairy wastewater treatment via AD (Krzemieniewski et al., 2004a-b). These were the basis for the development of the study on magnetoactive packing media for anaerobic biofilm reactor treated dairy wastewater, which established the value of magnetic induction (Zieliński et al., 2014) and the ratio of introduced metal ions (Zieliński et al.,in press). A new packing material produced by extrusion method was characterized by microspheres, which increase the active surface accessible to anaerobic microorganisms and catalytic properties due to the presence of metal ions $(\mathrm{Cu}$ and $\mathrm{Fe}$ ) and magnetic activators. In laboratory and small scale, the application of the new magneto-active media in $\mathrm{AD}$ of dairy wastewater enhanced organic matter removal and phosphorus removal and improved biogas production (Zieliński et al., 2015; Dębowski et al., 2014). However, this innovative solution has not been used before in dairy wastewater treatment on a large scale.

The aim of this study was to determine the effect of the magneto-active microporous packing media manufactured by extrusion and modified by the addition of metal catalysts and magnetic activation on $\mathrm{AD}$ of simulated dairy wastewater (SDW) and biogas production in a hybrid anaerobic biofilm reactor with full mixing operating on a pilot plant scale.

\section{MATERIALS AND METHODS}

\section{Wastewater}

In the present study, simulated dairy wastewater (SDW) was prepared by dissolving milk powder manufactured by Dairy Plant in Ostrowia Mazowiecka (Poland) per litre of distilled water to achieve COD concentrations according to the required OLRs: 5.0; $6.0 ; 7.0 ; 8.0 ; 9.0 ; 10.0 \mathrm{~kg} \mathrm{COD} / \mathrm{m}^{3} \cdot \mathrm{d}$. The method used for the OLR calculation was given by Zeeman and Lettinga (1999) and was based on the active volume of the reactor. Several investigators used the same method for making SDW (Leal et al., 2006; Kushwahaet al., 2010). SDW before feeding into the anaerobic reactor was kept at a temperature of $35^{\circ} \mathrm{C}\left( \pm 1^{\circ} \mathrm{C}\right)$ in a hydrolysis tank. The wastewater characteristics used at each stage of experiment are presented in Table 1.

\section{Magneto-active packing media preparation}

The biofilm support active media used in the experiment was manufactured by microporous extrusion of granulated transparent and plasticised polyvinyl chloride (PVC). PVC, commercially available as Alfavinyl GFM/4-31-TR, was manufactured by Alfa Sp. $\mathrm{z}$ o.o. (Poland). Major parameters of the PVC used in the experiment are as follows: density $1230 \mathrm{~kg} / \mathrm{m}^{3}$, Young's modulus $2600 \mathrm{MPa}$, tensile strength $21 \mathrm{MPa}$, elongation at break $300 \%$, shore A-hardness $80{ }^{\circ} \mathrm{Sh}$. When manufacturing the packing media, PVC was modified by the introduction of $0.8 \%$ wt granulated blowing agent Hydrocerol 530 (Clariant Masterbatch). Additionally, the PVC was blended with chemically pure copper and iron powder (Cometox). Each time $5.0 \%$ wt. of metal additives was introduced to PVC used for the production of packing elements. The copper to iron weight ratio was $1_{\mathrm{Cu}}: 9_{\mathrm{Fe}}$ and was set following previous studies carried out by the authors (Zieliński et al., 2016). Characteristics of the manufactured active media are as follows: density $874 \pm 0.8 \mathrm{~kg} / \mathrm{m}^{3}$, shore A-hardness $24 \pm 0.4^{\circ} \mathrm{Sh}$, tensile strength $138.1 \pm 1.8 \mathrm{~N}$, porosity $40 \pm 0.6 \%$. 
Table 1. Characteristics of SDW used in the study.

\begin{tabular}{|c|c|c|c|c|}
\hline Parameter & Unit & $\begin{array}{c}\text { Stage } 1 \\
5.0 \mathrm{~kg} \mathrm{COD} / \mathrm{m}^{3} \cdot \mathrm{d}\end{array}$ & $\begin{array}{c}\text { Stage } 2 \\
6.0 \mathrm{~kg} \mathrm{COD} / \mathrm{m}^{3} \cdot \mathrm{d}\end{array}$ & $\begin{array}{c}\text { Stage } 3 \\
7.0 \mathrm{~kg} \mathrm{COD} / \mathrm{m}^{3} \cdot \mathrm{d}\end{array}$ \\
\hline COD & $\mathrm{g} / \mathrm{L}$ & $10.01 \pm 0.10$ & $12.09 \pm 0.97$ & $14.11 \pm 0.12$ \\
\hline $\mathrm{TN}$ & $\mathrm{mg} / \mathrm{L}$ & $293.5 \pm 17.5$ & $356 \pm 20.9$ & $410 \pm 31.5$ \\
\hline $\mathrm{AN}$ & $\mathrm{mg} / \mathrm{L}$ & $24.8 \pm 3.6$ & $31.5 \pm 4.6$ & $38.3 \pm 7.4$ \\
\hline TP & $\mathrm{mg} / \mathrm{L}$ & $61.1 \pm 6.9$ & $73.32 \pm 11.7$ & $85.4 \pm 6.9$ \\
\hline TS & $\mathrm{mg} / \mathrm{L}$ & $17.6 \pm 6.2$ & $23.8 \pm 1.9$ & $29.7 \pm 4.6$ \\
\hline Parameter & Unit & $\begin{array}{c}\text { Stage } 4 \\
8.0 \mathrm{~kg} \mathrm{COD} / \mathrm{m}^{3} \cdot \mathrm{d}\end{array}$ & $\begin{array}{c}\text { Stage } 5 \\
9.0 \mathrm{~kg} \mathrm{COD} / \mathrm{m}^{3} \cdot \mathrm{d}\end{array}$ & $\begin{array}{c}\text { Stage } 6 \\
10.0 \mathrm{~kg} \mathrm{COD} / \mathrm{m}^{3} \cdot \mathrm{d}\end{array}$ \\
\hline COD & $\mathrm{g} / \mathrm{L}$ & $16.23 \pm 0.17$ & $18.23 \pm 0.64$ & $20.74 \pm 0.89$ \\
\hline $\mathrm{TN}$ & $\mathrm{mg} / \mathrm{L}$ & $472 \pm 27.7$ & $538 \pm 50.2$ & $603 \pm 59.1$ \\
\hline AN & $\mathrm{mg} / \mathrm{L}$ & $43.4 \pm 11.3$ & $46.9 \pm 7.2$ & $52.4 \pm 6.1$ \\
\hline $\mathrm{TP}$ & $\mathrm{mg} / \mathrm{L}$ & $97.1 \pm 9.3$ & $103.1 \pm 20.4$ & $119.02 \pm 13.5$ \\
\hline TS & $\mathrm{mg} / \mathrm{L}$ & $34.1 \pm 5.2$ & $34.8 \pm 5.3$ & $43.2 \pm 7.4$ \\
\hline
\end{tabular}

Based on previous experiments, it was assumed that suitable magnetic properties can be achieved by the introduction of magnets to $25 \%$ of the plastic elements placed inside the reactor (Zieliński et al., 2015). Characteristics of the neodymium magnets used in the experiments are as follow: diameter $10 \pm 0.1 \mathrm{~mm}$, height $5 \pm 0.1 \mathrm{~mm}$, magnetic flux $\sim 3952 \cdot 10^{-3} \mathrm{mWb}$, magnetic moment $\sim 450.528 \cdot 10^{-6} \mathrm{mWb} \cdot \mathrm{m}$, magnetic field in the geometrical center of the surface of the magnetic pole with a distance of $0.7 \mathrm{~mm} \sim 0.368 \mathrm{~T}$, magnetic field next to the edge of the surface of the magnetic pole (max.) with a distance of $0.7 \mathrm{~mm} \sim 0.384 \mathrm{~T}$, pull force $0.85 \mathrm{~kg}$.

\section{Experimental station setup and operation}

A pilot plant scale station for anaerobic treatment of SDW included a hydrolysis tank and a MA-HAB reactor (Fig. 1).
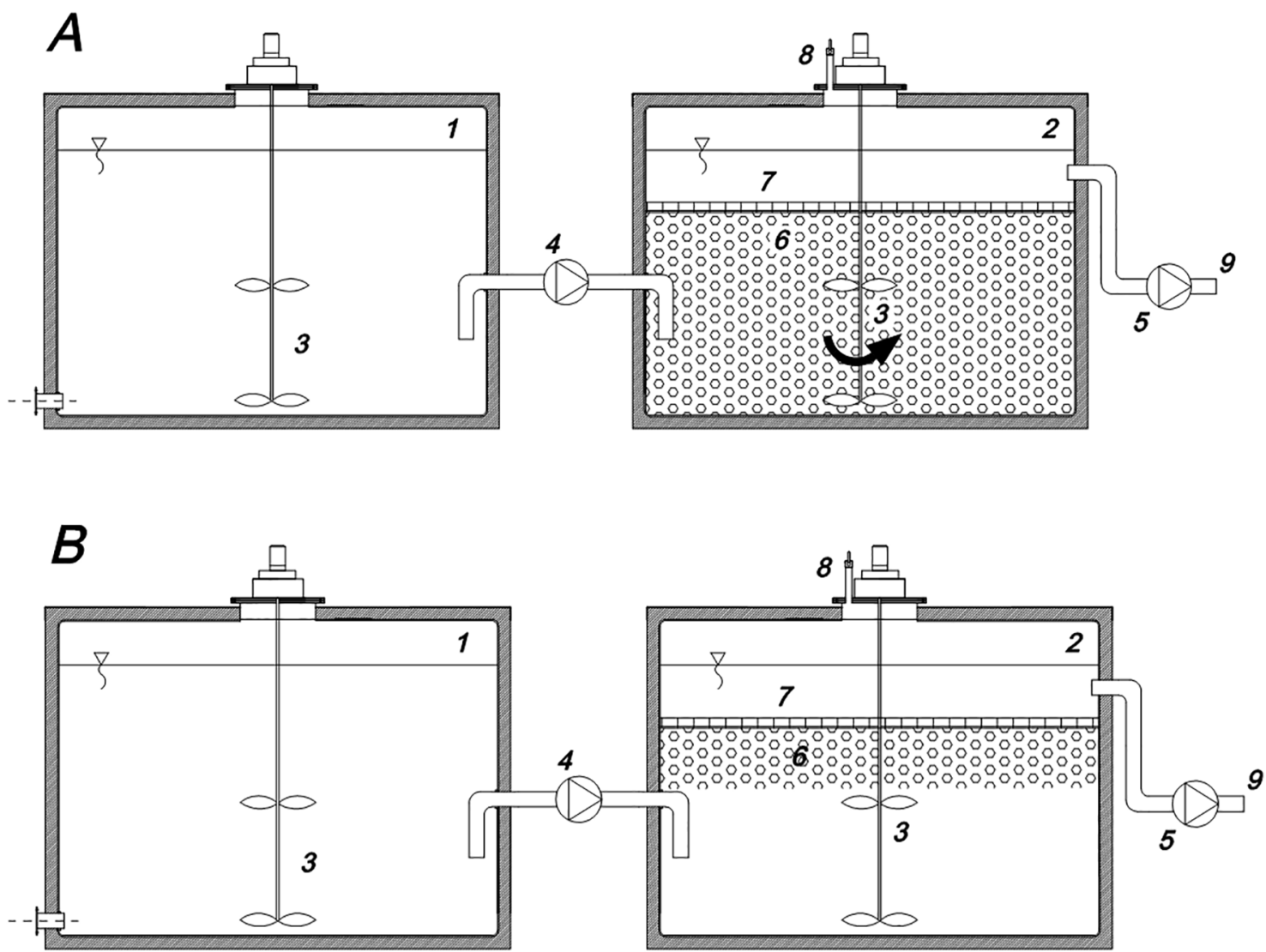

Figure 1. Scheme of a pilot plant scale station: a) operated as a contact reactor with a fluidised bed (mixing phase), b) during filtering layer formation (reaction phase); 1 - hydrolysis tank, 2 - MA-HAB reactor, 3 - mixer, 4 - rotary lobe pump, 5 - peristaltic pump, 6 - magneto-active filtering layer, 7 - membrane, 8 - biogas output, 9 - effluent. 
The hydrolysis tank was a DPPL type container of $1000 \mathrm{~L}$ total volume and $600 \mathrm{~L}$ active volume, fitted with a vertical mixer operating at a speed of $30 \mathrm{rpm}$. Once every $48 \mathrm{~h}$ SDW was prepared in the hydrolysis tank. SDW was fed to MA-HABR with the frequency of 24 times per $24 \mathrm{~h}$ for $10 \mathrm{~min}$, using a rotary lobe pump of $75 \mathrm{~L} / \mathrm{h}$ capacity.

The MA-HABR was designed as a DPPL type container of $1000 \mathrm{~L}$ total volume and $600 \mathrm{~L}$ active volume, fitted with a vertical mixer operating at a speed of $60 \mathrm{rpm}$. The mixer worked in a $30 \mathrm{~min}$ $\mathrm{ON}$ and $30 \mathrm{~min}$ OFF cycle per hour. The MAHABR was initially inoculated at a ratio of $40 \%$ (by volume). The inoculum originated from the closed fermentation tanks of a local municipal wastewater treatment plant. The concentration of volatile solids (VS) seeded into the reactor was $62.7 \%$ total solids (TS). The MA-HABR was filled with $200 \mathrm{~L}$ of an active medium. The density of the active medium was lower than that of the reactor contents (a mixture of anaerobic sludge and SDW), so during the mixing the tank was operated as a contact reactor with a fluidised bed (Fig. 1a). One cycle of MA-HABR reactor operating phase $(1 \mathrm{~h})$ consisted of $30 \mathrm{~min}$ of mixing and $30 \mathrm{~min}$ of reaction phase (without mixing). The reaction phase was divided into flotation of the media and the magneto-active filtering layer formation (10 min) (Fig. 1b), effluent discharge through the magneto-active filtering layer (10 min), filling with SDW $(10 \mathrm{~min})$. The temperature in the reaction chamber of the MA-HABR was $35^{\circ} \mathrm{C}\left( \pm 1^{\circ} \mathrm{C}\right)$ and was maintained automatically. Biogas was simply vented into the atmosphere.

The MA-HABR after the start-up period was operated under an increasing OLR ranging from $5.0 \mathrm{~kg} \mathrm{COD} / \mathrm{m}^{3} \cdot \mathrm{d}$ to $10.0 \mathrm{~kg} \mathrm{COD} / \mathrm{m}^{3} \cdot \mathrm{d}$ (six stages of the experiment). This type of technological procedure allowed determination of the acceptable OLR in the MA-HABR. The reactor was operated to reach a steady state at every OLR tested (the steady state was defined as the state where the standard deviations of COD removal efficiencies were within 5\%), a total of 229 days. The start-up period and adaptation of MA-HABR at a loading of $5.0 \mathrm{~kg} \mathrm{COD} / \mathrm{m}^{3} \cdot \mathrm{d}$ lasted for a period of 37 days. Then, the concentration of biofilm adhered to the support material and suspended biomass inside the reaction chamber were calculated. The concentration of adhered biomass was $1.53 \mathrm{~g}$ TS/L of the active medium, while the suspended biomass was $3.75 \mathrm{~g} \mathrm{TS} / \mathrm{L}$.

\section{Analytical methods}

The chemical oxygen demand (COD), total nitrogen (TN), ammonia nitrogen (AN), total phosphorus (TP), orthophosphate $\left(\mathrm{P}-\mathrm{PO}_{4}\right)$ in the SDW and effluent were analysed once every $24 \mathrm{~h}$ using a DR 5000 spectrophotometer (Hach, Germany). The content of total solids (TS) was determined according to the gravimetric method. Determination of the amount of biomass immobilized on the surface of magneto-active packing media was based on the weight method. Before/after biomass immobilization, the mass of pure/immobilized packing media was determined. For this purpose, 30 weight measurements of the 10 randomly selected packing media were used. In case of immobilized biomass determination, the packing media was dryied at $105{ }^{\circ} \mathrm{C}$ to evaporate water before weight measurement. TS of the immobilized biomass was determined by the difference between the average weight of the immobilized packing media and the average weight of the pure packing media. The tritation method (Tritlab AT 1000, Hach, Germany) was used for the determination of FOS/TAC ratio (volatile organic acid and buffer capacity ratio).

Biogas flow rate was measured continuously using a digital gas flow meter XFM17S (Aalborg Instruments \& Controls, Inc., USA). The biogas composition was analysed once every $24 \mathrm{~h}$ using a GMF 430 meter (GasData, England) and a gas chromatograph (GC, 7890A Agilent, USA) equipped with a thermal conductivity detector (TCD). The GC was fitted with two Hayesep Q columns (80/100 mesh), two molecular sieve columns (60/80 mesh) and a Porapak Q column $(80 / 100)$ operating at a temperature of $70^{\circ} \mathrm{C}$. The temperature of the injection and detector ports were $150^{\circ} \mathrm{C}$ and $250^{\circ} \mathrm{C}$, respectively. Helium and argon were used as the carrier gases at a flow of $15 \mathrm{~mL} / \mathrm{min}$.

Statistical analysis of results was carried out using the STATISTICA 10.0 PL software package. The hypothesis of the distribution of each analysed variable was verified using the W Shapiro-Wilk test. One-way analysis of variance (ANOVA) was used to determine the significance of differences between variables. The homogeneity of variance in the groups was analysed using Levene's test. The RIR Tukey test was used to determine the significance of differences between the analysed variables. The statistical significance was adopted at $\mathrm{p}=0.05$. 


\section{RESULTS AND DISCUSSION}

\section{Organic matter and nutrients removal}

Most hybrid reactors treating dairy effluents have been operated in lab-scale systems (Karadag et al., 2015). In our study the HABR was operated on a pilot plant scale and contained an innovative magnetoactive packing media.

The results showed that a pilot plant scale MA$\mathrm{HAB}$ reactor has a high potential in organic matter and phosphorus removal from SDW. The start-up period and adaptation of MA-HABR at a loading of $5.0 \mathrm{~kg} \mathrm{COD} / \mathrm{m}^{3} \cdot \mathrm{d}$ was 37 days (Table 2). During the MA-HABR operation, the highest COD removal efficiency of $75.8-77.5 \%$ was achieved under the OLR range of $6.0-7.0 \mathrm{~kg} \mathrm{COD} / \mathrm{m}^{3} \cdot \mathrm{d}$ (Fig. 2, Table 2). Increase in the OLR gradually deteriorated the COD removal efficiency; however, the COD removal achieved in stage 5 (OLR of $\left.9.0 \mathrm{~kg} \mathrm{COD} / \mathrm{m}^{3} \cdot \mathrm{d}\right)$ was comparable to that at the lowest OLR of $5.0 \mathrm{~kg} \mathrm{COD} /$ $\mathrm{m}^{3} \cdot \mathrm{d}$. The removed COD loading reached the maximum level of $3.5-3.6 \mathrm{~g} / \mathrm{d}$ under the OLR of $9.0-10.0 \mathrm{~kg} \mathrm{COD} /$ $\mathrm{m}^{3} \cdot \mathrm{d}$. The lowest removed COD of $2.0 \mathrm{~g} / \mathrm{d}$ was achieved in the first stage of the experiment. The efficiency of TS removal exceeded $94 \%$ in all stages, and was the highest (over 97\%) when the OLR ranged from 7.0 -10.0kg COD/ $\mathrm{m}^{3} \cdot \mathrm{d}$. Throughout the study, the concentration of TS in the effluent remained at $0.38-0.47 \mathrm{~g} / \mathrm{L}$.

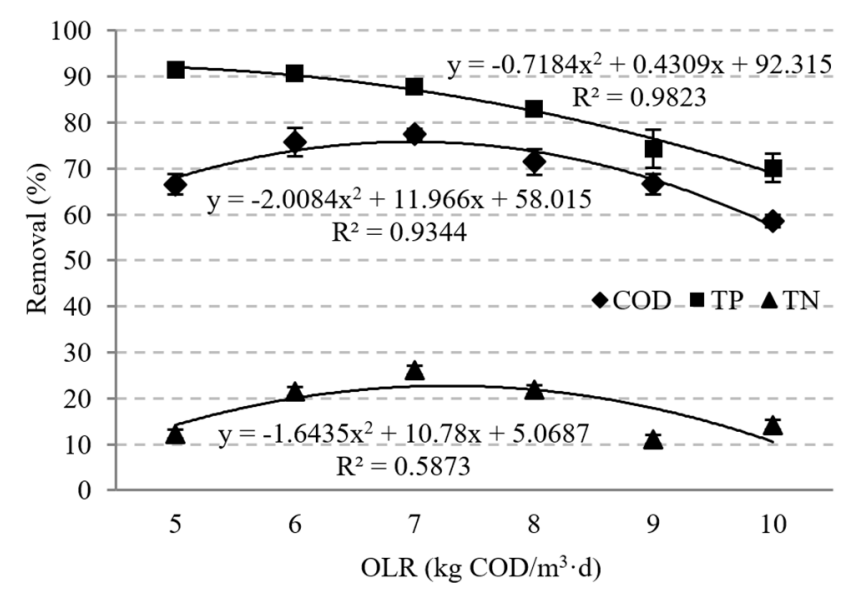

Figure 2. OLR-dependent profile of COD, total nitrogen $(\mathrm{TN})$ and total phosphorus (TP) removal efficiency.

The highest TN removal of $21.5-26.1 \%$ was achieved when the OLR ranged from $6.0-8.0 \mathrm{~kg}$ $\mathrm{COD} / \mathrm{m}^{3} \cdot \mathrm{d}$ (Fig. 2, Table 2). Further OLR increase resulted in nitrogen removal deterioration below $15 \%$, which was similar $(p>0.01)$ to the value achieved at the first stage of the experiment. As regards the phosphorus removal, it exceeded $70 \%$ throughout the study (Fig.2, Table 2). At OLR in the range of $5.0-8.0 \mathrm{~kg} \mathrm{COD} / \mathrm{m}^{3} \cdot \mathrm{d}$, the outflow TP concentration was $12-18 \mathrm{mg} / \mathrm{L}$, while phosphorus removal was over $83 \%$. Clogging was not observed during the operation time, and the catalytic properties of the packing media were not reduced.

Table 2. Mean values of the reactor monitoring data reached at each stage of the experiment.

\begin{tabular}{|c|c|c|c|c|c|c|}
\hline & Stage 1 & Stage 2 & Stage 3 & Stage 4 & Stage 5 & Stage 6 \\
\hline \multicolumn{7}{|c|}{ Operating conditions } \\
\hline $\begin{array}{l}\text { OLR (kg COD/ } \\
\left.\mathrm{m}^{3} \cdot \mathrm{d}\right)\end{array}$ & 5.0 & 6.0 & 7.0 & 8.0 & 9.0 & 10.0 \\
\hline Time (d) & 37 & 35 & 36 & 38 & 42 & 41 \\
\hline \multicolumn{7}{|c|}{ Operating at steady-state } \\
\hline COD removal (\%) & 66.5 & 75.8 & 77.5 & 71.4 & 66.6 & 58.6 \\
\hline TP removal (\%) & 91.5 & 90.7 & 87.9 & 83.0 & 74.3 & 70.1 \\
\hline TN removal (\%) & 12.3 & 21.5 & 26.1 & 21.9 & 11.1 & 14.3 \\
\hline $\begin{array}{l}\text { Biogas yield }(\mathrm{L} / \mathrm{kg} \\
\left.\mathrm{COD}_{\text {removed }}\right)\end{array}$ & 291.7 & 310.9 & 296.8 & 256.7 & 170.3 & 120.0 \\
\hline $\mathrm{CH} 4$ in biogas $(\%)$ & 68.0 & 68.0 & 61.0 & 49 & 52 & 47 \\
\hline $\operatorname{VBPR}(\mathrm{L} / \mathrm{d})$ & 591.9 & 847.8 & 966.8 & 881.7 & 616.8 & 453.7 \\
\hline $\operatorname{VMPR}\left(\mathrm{L} / \mathrm{CH}_{4} / \mathrm{d}\right)$ & 410.5 & 557.1 & 593.3 & 420.6 & 329.5 & 217.0 \\
\hline $\mathrm{pH}$ & 7.3 & 7.2 & 6.8 & 6.7 & 6.7 & 6.7 \\
\hline FOS/TAC ratio & 0.31 & 0.35 & 0.36 & 0.37 & 0.44 & 0.46 \\
\hline
\end{tabular}


In the presented study, an innovative active medium made of PCV elements modified with metal catalyst containing $\mathrm{Cu}$ and $\mathrm{Fe}$ was used.The results demonstrated that the addition of catalysts allowed for the effective removal of organic matter (as COD over 58\%) and phosphorus (over 70\%). Moreover, dairy effluent was discharged from the reactor via a filtering layer formed by a magneto-active packing media that created an additional surface for the growth of microorganisms, and can play a significant role in the removal of solids suspended in wastewater by prolonging the HRT necessary for the biodegradation of complex organic compounds (Haridas et al., 2005). Thus, the effectiveness of TS removal was over $94 \%$ during the study.

Similar conclusions were made by JędrzejewskaCicińska and Krzemieniewski (2010), who used steel elements to fill an UASB reactor during the treatment of dairy wastewater. Depending on the applied OLR, the efficiencies of phosphorus and COD removal were respectively higher by $16.4-68.1 \%$ and $1.0-3.1 \%$ in the reactor filled with steel elements as compared to performance rates achieved in a conventional UASB system. Zhang et al . (2011) reported a 53\% increase in the COD removal in an UASB reactor filled with iron elements as compared to the efficiency noted in a digester without such elements. Shi et al. (2011) observed an 8.7-14.9\% increase in COD removal and an over $68.5 \%$ increase in phosphorus removal in an UASB reactor supplemented with zero-valent iron $\left(\mathrm{Fe}^{0}\right)$. Wu et al. (2015) achieved a $70.9 \%$ increase in phosphates removal and a $27.6 \%$ increase in COD removal from swine production wastewater using a treatment system supplemented with zero-valent iron (ZVI). Jeon et al. (2003) improved the removal of organic matter and phosphorus from municipal and household wastewater by using steel rings to fill an Upflow Anaerobic Fluidised Bed Reactor (UAFBR).

Corrosion of metal elements stimulates the biochemical degradation of organic compounds by modification of the anaerobic environment inside the reactor through a reduction in the oxidationreduction potential (ORP) and an increase in the buffer capacity (Zhang et al., 2011; Wu et al., 2015). It also enhances abiotic processes of contaminant removal, because the formed colloids (i.e., $\mathrm{Fe}(\mathrm{OH})_{2}$ and $\mathrm{Fe}(\mathrm{OH})_{3}$ ) help to eliminate organic suspended solids in flocculation, adsorption and precipitation reactions (Jeon et al., 2003; Noubacept, 2008). Moreover, insoluble vivianite compounds are formed in the reaction of metal ions with phosphates, which reduces phosphorus concentration in the treated wastewater (Shi et al., 2011; Wu et al., 2015). Similar processes can be used for the removal of nitrogen compounds. Ammonium ions can form complexes with iron ions, which leads to a reduction in the concentration of total nitrogen in treated wastewater. However during the study, the TN removal was not high (11.1 - 26.1\%). The major environmental factors influencing methanogenesis are the volatile fatty acids (VFAs), ammonia nitrogen and $\mathrm{pH}$ (Fotidis et al., 2013). During the study, AN concentration in the effluent increased along with increasing OLR. Under the OLR of $5.0-8.0 \mathrm{~kg} \mathrm{COD} / \mathrm{m}^{3} \cdot \mathrm{d}$ it ranged from 171.1 to $263.1 \mathrm{mg}$ AN/L. AN reached the maximum value of $318.5 \mathrm{mg} / \mathrm{L}$ when the OLR was $9.0 \mathrm{~kg} \mathrm{COD} /$ $\mathrm{m}^{3} \cdot \mathrm{d}$. At the last stage of the experiment it was 302.3 $\mathrm{mg}$ AN/L. During the 229 days of operation time, the $\mathrm{pH}$ was maintained at $6.8-7.3$ when the OLR was $5.0-7.0 \mathrm{~kg} \mathrm{COD} / \mathrm{m}^{3} \cdot \mathrm{d}$, and then it was dropped to $\mathrm{pH} 6.7$ under the OLR of $8.0-10.0 \mathrm{~kg} \mathrm{COD} / \mathrm{m}^{3} \cdot \mathrm{d}$ (Table 2). FOS/TAC ratio was determined at each stage of experiment to evaluate the stability of the anaerobic degradation process (Table 2). The FOS/TAC ratio changed between 0.31 and 0.44 . During anaerobic digestion of dairy wastewater, the nitrogen in proteins is converted to inorganic forms, including ammonia. Ammonia, especially free ammonia, is the major toxicant in anaerobic digesters and its concentration over $4 \mathrm{~g} / \mathrm{L}$ may inhibit methanogenesis (Westerholm et al., 2011). According to Chen et al. (2008), an ammonia concentration below $200 \mathrm{mg} / \mathrm{L}$ is beneficial for anaerobic microorganisms as a nitrogen nutrient source. An increase in $\mathrm{pH}$ would result in increased ammonia toxicity; thus, the most favorable $\mathrm{pH}$ for methane production ranged from 6.5 to 7.5 (Lili et al., 2011). In our study, the concentrations of AN were below inhibiting concentrations and the maximum $\mathrm{pH}$ value was 7.3. Thus, AN was at a safe level at the all stages of experiment. Moreover, AD instability due to ammonia often results in VFAs accumulation, which leads to a decrease in $\mathrm{pH}$. There was no acidification in our study, and the FOS/TAC ratio showed an optimal value ranging from 0.31 to 0.37 when the OLR ranged from 5.0 to $8.0 \mathrm{~kg} \mathrm{COD} / \mathrm{m}^{3} \cdot \mathrm{d}$. When the OLR increased to $9-10 \mathrm{~kg} \mathrm{COD} / \mathrm{m}^{3} \cdot \mathrm{d}$, the $\mathrm{FOS} / \mathrm{TAC}$ ratio increased to over 0.4 and biogas yield was suddenly reduced, which reflected the overloading of the digester.

\section{Biogas and methane production}

At OLR ranging from 5.0- 7.0 $\mathrm{kg} \mathrm{COD} / \mathrm{m}^{3} \cdot \mathrm{d}$, the biogas yield achieved about $300 \mathrm{~L} / \mathrm{kg} \mathrm{COD}{ }_{\text {removed }}$ and was the highest during all the study (Fig. 3, Table 2). The use of OLR of $9.0 \mathrm{~kg} \mathrm{COD} / \mathrm{m}^{3} \cdot \mathrm{d}$ significantly reduced the 
biogas yield below $180 \mathrm{~L} / \mathrm{kg} \mathrm{COD}$ removed. (Fig. 3). High volumetric biogas production rate (VBPR) was noted at OLR from 6.0 - $8.0 \mathrm{~kg} \mathrm{COD} / \mathrm{m}^{3} \cdot \mathrm{d}$; however, the VBPR reached the maximum value of $966.8 \mathrm{~L} / \mathrm{d}$ at an OLR of $7.0 \mathrm{~kg} \mathrm{COD} / \mathrm{m}^{3} \cdot \mathrm{d}$ (Fig. 4, Table 2). Similarly, the highest volumetric methane production rate (VMPR) was noted at OLR from $6.0-7.0 \mathrm{~kg} \mathrm{COD} / \mathrm{m}^{3} \cdot \mathrm{d}$ (Fig. 4, Table 2). Methane content in the biogas was on the average 61 $68 \%$ at OLR from $5.0-7.0 \mathrm{~kg} \mathrm{COD} / \mathrm{m}^{3} \cdot \mathrm{d}$ and decreased to $47 \%$ at higher OLRs (Table 2).

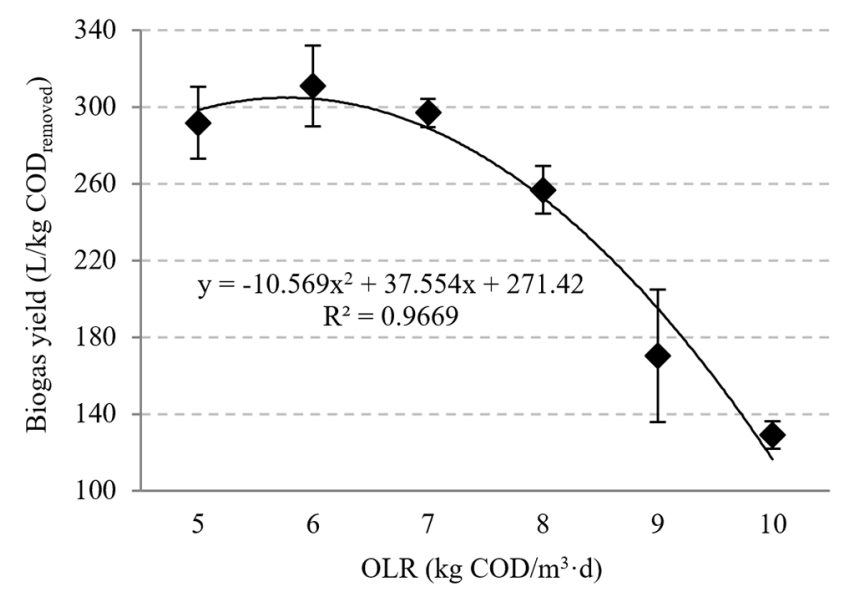

Figure 3. OLR-dependent profile of biogas yield.

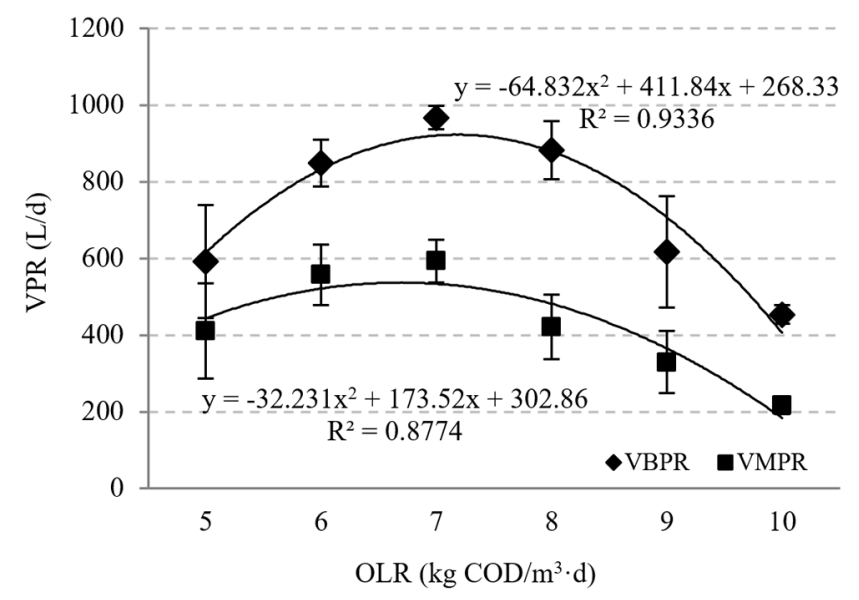

Figure 4. OLR-dependent profile of volumetric biogas and methane production rate (VBPR and VMPR).

In recent years, anaerobic biofilm reactors have been widely applied for the treatment of dairy wastewater with the OLR ranging from $0.83 \mathrm{~kg} \mathrm{COD} /$ $\mathrm{m}^{3} \cdot \mathrm{d}$ to $31.0 \mathrm{~kg} \mathrm{COD} / \mathrm{m}^{3} \cdot \mathrm{d}$ (Karadag et al. 2015). High-strength milk permeate wastewater from a cheese making process was treated under mesophilic conditions using a bench-scale anaerobic moving bed biofilm reactor (AMBBR) under OLR from 1.5 $\mathrm{kg} \mathrm{COD} / \mathrm{m}^{3} \cdot \mathrm{d}$ to $11.0 \mathrm{~kg} \mathrm{COD} / \mathrm{m}^{3} \cdot \mathrm{d}$ (Wang et al. 2009). The maximum methane yield of $313 \mathrm{~L} \mathrm{CH}_{4} / \mathrm{kg}$
$\mathrm{COD}_{\text {removed }}$ was achieved with the OLR of $9.5 \mathrm{~kg} \mathrm{COD} /$ $\mathrm{m}^{3} \cdot \mathrm{d}$. An anaerobic hybrid reactor with plastic cut rings for biofilm development was effectively used for the treatment of dairy wastewater by Banu et al. (2008). The methane production varied from 280 to $320 \mathrm{~L}$ $\mathrm{CH}_{4} / \mathrm{kg} \mathrm{COD} \cdot$ day and the methane content in biogas reached $60-65 \%$ under OLR from $8.4 \mathrm{~kg} \mathrm{COD} / \mathrm{m}^{3} \cdot \mathrm{d}$ to $19.2 \mathrm{~kg} \mathrm{COD} / \mathrm{m}^{3} \cdot \mathrm{d}$. Strydom et al. (1997) treated effluents from three dairy factories (cheese, fresh milk and milk powder/butter factories) using an anaerobic hybrid reactor. The methane yield varied from 287 to $359 \mathrm{~L} \mathrm{CH}_{4} / \mathrm{kg} \mathrm{COD}_{\text {removed }}$ at OLR between 0.97 and $2.82 \mathrm{~kg} \mathrm{COD} / \mathrm{m}^{3} \cdot \mathrm{d}$. In our study, the maximum biogas

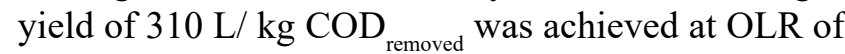
$6.0 \mathrm{~kg} \mathrm{COD} / \mathrm{m}^{3} \cdot \mathrm{d}$.

The corrosion of the magneto-active microporous mediamay affect methanogenesis. According to Karri et al. (2005), during anaerobic digestion, metal catalysts such as zero-valent iron are electrondonors for methanogenic and denitrifying bacteria. Under anaerobic conditions, iron corrosion is triggered by gaseous $\mathrm{H}_{2}$, and the formed $\mathrm{CO}_{2}$ is reduced to $\mathrm{CH}_{4}$ by hydrogenotrophic methanogens such as Methanococcus thermolithotrophicus, Methanobacterium thermoautotrophicum, or Methanospirillum hungatei (Wu et al., 2015). Shi et al. (2011) used iron nanoparticles to supplement the UASB reactor and obtained an increase in biogas productivity and methane content in biogas (by 12.9$17.9 \%$ and $10.7-12.9 \%$, respectively). In a study of an UASB reactor filled with iron elements, Zhang et al. (2011) achieved a $66.8 \%$ content of methane in biogas versus $47.9 \%$ in biogas generated in an UASB reactor without elements. An increase in the efficiency of methanogenesis in reactors filled with steel elements was also reported by other researchers (Shi et al., 2011; Liu et al., 2015).

Moreover, the magnetic properties of the active packing media used in the present study may enhance the metabolic activity of anaerobic microorganisms in the sludge. The earlier study showed that the value of magnetic induction of $0.38 \mathrm{~T}$ positively affected organic matter removal and biogas production (Zieliński et al., 2014). According to Ji et al. (2010), a suitable level of magnetic induction not greater than $17.8 \mathrm{mT}$ stimulates microbial activity, and thus improves the efficiency of wastewater treatment. For example, Krzemieniewski et al. (2004b) applied a stable magnetic field with induction of 0.4-0.6 T and achieved increased efficiency of COD, ammonia nitrogen and orthophosphates removal from municipal, household and dairy wastewater $(25-55 \%, 50-66 \%$, 
$87-90 \%$, respectively) when compared to removal rates in the system without magnetic field assistance. The magnetic field also modifies the properties of fluids, such as viscosity, enthalpy or surface tension (Toledo et al., 2008), which may result in more effective migration of gaseous metabolites of anaerobic microorganisms in the sludge from the reactor.

\section{CONCLUSION}

Anaerobic biofilm-based reactors are the most common reactor employed for dairy wastewater treatment. However, the main disadvantages of these reactors are the loss of the reactor performance due to the clogging of the filter material and only partial removal of non-organic pollution such as nutrients. There is a need to search for new biofilm support materials which could enhance the sorption, precipitation and the binding of biogenic compounds. This study demonstrated that the use of an innovative magneto-active packing medium ensured a stable organic matter removal (over 70\%), phosphorus removal (over $80 \%$ ) and biogas production (over 800 $\mathrm{L} / \mathrm{d}$ ) at OLR ranging from 6.0 to $8.0 \mathrm{~kg} \mathrm{COD} / \mathrm{m}^{3} \cdot \mathrm{d}$. The method of discharge of the effluent through the magneto-active layer enhanced the TS removal and reduced bacterial biomass losses, without clogging of the reactor. A significant decrease in biogas/methane production was found when the MA-HAB reactor was operated at an OLR greater than $8.0 \mathrm{~kg} \mathrm{COD} / \mathrm{m}^{3} \cdot \mathrm{d}$; however, organic matter and phosphorus removal were still high.

\section{ACKNOWLEDGEMENTS}

The research was conducted under Project POIG.01.01.02-14-034/09, entitled: Catalytic fillings for bioreactors for industrial wastewater treatment technology, sponsored by the Programme Innovative Technical Support Systems for Sustainable Development Task IV.5.2. and was also supported by Project No. 18.610.008-300 from the University of Warmia and Mazury in Olsztyn.

\section{REFERENCES}

Banu, J.R., Anandan, S., Kaliappan, S., Yeom, I.T., Treatment of dairy wastewater using anaerobic and solar photocatalytic methods. Solar Energy, 82, 812-819 (2008).

Chen, Y., Cheng, J.J., Creamer, K.S., Inhibition of anaerobic digestion process: A review. Bioresource Technology, 99, 4044-4046 (2008).
Chokshi, K., Pancha, I., Ghosh, A., Mishra, S., Microalgal biomass generation by phycoremediation of dairy industry wastewater: An integrated approach towards sustainable biofuel production. Bioresource Technology, 221, 455-460 (2016).

Dębowski, M., Zieliński, M., Krzemieniewski, M., Brudniak, A., Effect of magneto-active filling on the effectiveness of methane fermentation of dairy wastewaters. International Journal of Green Energy (2014), doi: 10.1080/15435075.2014.909362

Eurostat Statistics Explained: Milk and milk product statistics. http://ec.europa.eu/eurostat/statisticsexplained/index.php/Milk and milk product statistics (accessed October 2015)

Fotidis, I.A., Karakashev, D., Kotsopoulos, T.A., Martzopoulos, G.G., Angelidaki, I., Effect of ammonium and acetate on methanogenic pathway and methanogenic community composition. FEMS Microbilogy Ecology, 83, 38-48 (2013).

Gugała, M., Zarzecka, K., Sikorska, A., Wastewater management in food processing enterprises - a case study of the Ciechanów Dairy Cooperative. Journal of Ecological Engineering, 16, 178-183(2015).

Haridas, A., Suresh, S., Chitra, K.R., Manilal, V.B., The Buoyant Filter Bioreactor: a high-rate anaerobic reactor for complex wastewater - process dynamics with dairy effluent. Water Research, 39, 993-1004 (2005).

Ince, O., Ince, B.K., Donnelly, T., Attachment, strength and performance of a porous media in an upflow anaerobic filter treating dairy wastewater. Water Science Technology, 41, 261-270 (2000).

Jędrzejewska-Cicińska, M., Krzemieniewski, M., Effect of corrosion of steel elements on the treatment of dairy wastewater in a UASB reactor. Environmental Technology, 31, 585-589 (2010).

Jeon, S.J., Kim, H.S., Lee, Y.W., Effect of iron media on the treatment of domestic wastewater to enhance nutrient removal efficiency. Process Biochemistry, 38, 1767-1773 (2003).

Ji, Y., Wang, Y., Sun, J., Yan, T., Li, J., Zhao, T., Yin, X., Sun, C., Enhancement of biological treatment of wastewater by magnetic field. Bioresource Technology, 101, 8535-8540 (2010).

Karadag, D., Köroğlu, O.E., Ozkaya, B., Cakmakci, M., A review on anaerobic biofilm reactors for the treatment of dairy industry wastewater. Process Biochemistry, 50, 262-271 (2015).

Karri, S., Sierra-Alvarez, R., Field, J.A., Zero valent iron as an electron-donor for methanogenesis and sulfate reduction in anaerobic sludge. Biotechnology and Bioengineering, 92, 810-819 (2005). 
Krzemieniewski, M., Dębowski, M., Dobrzyńska, A., Zieliński, M., Chemical oxygen demand reduction of various wastewater types using magnetic fieldassisted Fenton reaction. Water Environment Research, 76, 301-309 (2004a).

Krzemieniewski, M., Dębowski, M., Janczukowicz, W., Pesta, J., Effect of the Constant Magnetic Field on the Composition of Dairy Wastewater and Domestic Sewage. Polish Journal of Environmental Studies, 13, 45-53 (2004b).

Kushwaha, J.P., Srivastava, V.C., Mall, I.D., Organics removal from dairy wastewater by electrochemical treatment and residue disposal. Separation and Purification Technology, 76, 198-205(2010).

Leal, M.C.M.R., Freire, D.M.G., Cammarota, M.C., Sant'Anna Jr., G.L., Effect of enzymatic hydrolysis on anaerobic treatment of dairy wastewater. Process Biochemistry, 41, 1173-1178(2006).

Lili, M., Biró, G., Sulyok, E., Petis, M., Borbély, J., Tamás, J., Novel approach on the basis of FOS/TAC method. Analele Universităt ii din Oradea, Fascicula Protecţia Mediului, XVII, 713-718 (2011).

Liu, Y., Wang, Q., Zhang, Y., Ni, B.J., Zero valent iron significantly enhances methane production from waste activated sludge by improving biochemical methane potential rather than hydrolysis rate. Scientific Reports, v. 5: 8263 (2015).

Najafpour, G.D., Komeili, M., Tajallipour, M., Asadi, M., Bioconversion of cheese whey to methane in an upflow anaerobic packed bed bioreactor. Chemical and Biochemical Engineering Quarterly, 24, 111117 (2010)

Noubactep, C., A critical review on the process of contaminant removal in $\mathrm{Fe}^{0}-\mathrm{H}_{2} \mathrm{O}$ systems. Environmental Technology, 29, 909-920 (2008).

Qazi, J.I., Nadeem, M., Baig, S.S., Baig, S., Syed, Q., Anaerobic fixed film biotreatment of dairy wastewater. Middle-East Journal of Scientific Research, 8, 590-593 (2011).

Rajagopal, R., Saady, N.M.C., Torrijos, M., Thanikal, J.V., Hung, Y.T., Sustainable Agro-Food Industrial Wastewater Treatment Using High Rate Anaerobic Process. Water, 5, 292-311 (2013).

Shete, B.S., Shinkar, N.P., Dairy industry wastewater sources, characteristics and its effects on environment. International Journal of Current Engineering and Technology, 3, 1611-1615 (2013).

Shi, R., Xu, H., Zhang, Y., Enhanced treatment of wastewater from the vitamin $\mathrm{C}$ biosynthesis industry using a UASB reactor supplemented with zero-valent iron. Environmental Technology, 32, 1859-1865 (2011).
Strydom, J.P., Britz, T.J., Mostert, J.F., Two-phase anaerobic digestion of three different dairyeffluents using a hybrid bioreactor. Water SA, 23, 151-156 (1997).

Tiwary, A., Williams, I.D., Pant, D.C., Kishore, V.V.N., Emerging perspectives on environmental burden minimisation initiatives from anaerobic digestion technologies for community scale biomass valorization. Renewable and Sustainable Energy Reviews, 42, 883-901 (2015).

Toledo, E.J.L., Ramalho, T.C., Magriotis, Z.M., Influence of magnetic field on physical-chemical properties of the liquid water: Insights from experimental and theoretical models. Journal of Molecular Structure, 888, 409-415 (2008).

Wang, S., Rao, N.C., Qiu, R., Moletta, R., Treatability and kinetic analysis of anaerobic moving bed biofilm reactor treating high strength milk permeate. Desalination and Water Treatment, 94, 191-197 (2009).

Westerholm, M., Müller, B., Arthurson, V., Schnürer, A., Changes in the acetogenic population in a mesophilic anaerobic digester in response to increasing ammonia concentration. Microbes and Environments, 26, 347-353 (2011).

Wu, D., Zheng, S., Ding, A., Sun, G., Yang, M., Performance of a zero valent iron-based anaerobic system in swine wastewater treatment. Journal of Hazardous Materials, 286, 1-6 (2015).

Zeeman, G., Lettinga, G., The role of anaerobic digestion of domestic sewage in closing the water and nutrient cycle at community level, Water Science and Technology, 39, 187-194 (1999).

Zhang, Y., Jing, Y., Quan, X., Liu, Y., Onu, P., A BuiltIn Zero Valent Iron Anaerobic Reactor to Enhance Treatment of Azo Dye Wastewater. Water Science and Technology, 63, 741-746 (2011).

Zieliński, M., Dębowski, M., Krzemieniewski, M., Brudniak A. , Effectiveness of dairy wastewater treatment in anaerobic reactors with magnetoactive filling. Environmental Progress and Sustainable Energy, 34, 427-431 (2015).

Zieliński, M., Dębowski, M., Krzemieniewski, M., Brudniak, A., Kisielewska, M., Possibility of improving technological effectiveness of dairy wastewater treatment through application of active fillings and microwave radiation. Journal of Water Chemistry and Technology, 38(6), 342-348 (2016).

Zieliński, M., Dębowski, M., Krzemieniewski, M., Dudek, M., Grala, A., Effect of the constant magneticfield $(\mathrm{CMF})$ with various values of magnetic induction on the effectivenessof dairy wastewaters treatment under anaerobicconditions. Polish Journal of Environmental Studies, 23, 255-261 (2014). 
562 Marcin Dębowski, Marcin Zieliński, Marta Kisielewska, Mirosław Krzemieniewski, Monika Makowska, Marian Grądkowski and Aneta Tor-Świątek 